\title{
Tracheal Injuries
}

\author{
Trakeal Yaralanmalar
}

\section{Ahmet Gökhan \\ GÜNDOĞDU* \\ Fatma Özlem \\ YAZKAN** \\ Rasih YAZKAN* \\ *:Süleyman Demirel \\ Üniversitesi, Tip Fakültesi, \\ Göğü Cerrahisi AD, Isparta \\ ** Isparta Şehir Hastanesi \\ Kulak Burun Boğaz Kliniği, Isparta}

Yazışma Adresi:

Ahmet Gökhan Gündoğdu

gokhangundogdu@hotmail.com

533/2506281

Süleyman Demirel Üniversitesi, Tıp

Fakültesi Göğüs Cerrahisi AD

Çünür mah. 32246, Isparta

\section{$\ddot{O ̈ z}_{z}$}

Trakea yaralanmaları nadir olmalarına karşın ani ölüme neden olabilmeleri açısından önemlidir. Hastaneye geliş öncesi tıbbi bakımın gelişip iyileşmesine bağlı olarak zaman içerisinde insidansın artması beklenmektedir. Künt veya delici travma, iatrojenik nedenler, iple boğulma, yanıklar ve kostik madde yutulması trakea yaralanmalarına neden olur. Trakeal yaralanmaların olmazsa olmazı şüphe, erken tanı ve zamanında tedavidir.

Anahtar Kelimeler: Trakea, yaralanma

\begin{abstract}
Tracheal injuries, although uncommon, are yet very important since they can lead to immediate death. With the improvement of prehospital medical care, the incidence is expected to increase in time. Blunt or penetrating trauma, iatrogenic causes, strangulation, burns and caustic material ingestion give rise to tracheal injuries. Mainstay of the tracheal injuries is suspicion, early diagnosis and prompt management.
\end{abstract}

Keywords: Trachea, injury

\section{Tracheal Injuries}

Tracheal injuries, although uncommon, are yet very important since they can lead to immediate death. The rarity of the tracheal injuries may be closely related to the fact that the impact causing the injury is really immense and most patients cannot survive to make it to the hospital. Those injuries, which remain undiagnosed at the time of the impulse, may give rise to strictures in the tracheal hollow. The first 
ever surviving tracheobronchial injury was reported by Winslow in 1871 (1), even though that might not have been the exact phenomenon as debated by Treasure $(1,2)$.

The trachea lies between the cricoid cartilage and the carina, where it finally separates into two main bronchi. Adult trachea is around 10 to $13 \mathrm{~cm}$ in length and harbors 18 to 22 cartilaginous rings (3). It is both cervical and intrathoracic. Generally speaking, first half of the trachea lies in the neck, whereas the remaining half resides in mediastinum. This varies with people of different stature, body habitus and position of the neck. Trachea may be mobile in the cephalocaudal axis, but it is fairly stationary in anteroposterior axis. The normal anatomy of the trachea and the neighboring organs should always be kept in mind in order to evaluate the possible mechanism and anatomical location of the injury following different kinds of tracheal trauma.

\section{Incidence and Mechanism of Tracheal Injuries}

Tracheal injuries result from a couple of reasons such as penetrating trauma, blunt trauma, iatrogenic issues, strangulation, caustic injuries and tracheal burns following inhalation of noxious fumes. Iatrogenic injuries are most often related to tracheal intubation $(4,5)$.

The real incidence is cumbersome to evaluate since most patients don't have the chance to survive to the hospital (6).

Penetrating tracheobronchial injury constitutes around $2 \%$ of thoracic trauma admissions (7). Penetrating traumas commonly involve the cervical part of the trachea. For blunt trauma the incidence was found to be $2.8 \%$ by Bertelsen and Howitz, who reviewed 1178 autopsy reports of casualties of blunt injury (8). Around $80 \%$ tracheobronchial injuries caused by blunt trauma are located within $2.5 \mathrm{~cm}$ of the carina (9).

Blunt or penetrating trauma, iatrogenic causes, strangulation, burns and caustic material ingestion give rise to tracheal injuries. Stab injuries are most often cervical, whereas gunshot injuries involve any part of the trachea, cervical portion still being the most common location (7). Blunt injuries of the cervical trachea result from direct trauma or sudden hyperextension of the neck. Four potential mechanisms for blunt intrathoracic tracheobronchial injury have been defined $(7,10)$. First one is forceful anteroposterior compression. The lungs are normally stationary inside the chest wall. The movement of the lungs away from the trachea produces a huge tension at the level of carina, where the trachea is stationary.

Second mechanism is high airway pressure leading to airway rupture. Membranocartilaginous junction and the distance between the two cartilaginous rings are most prone to the impact (11). Third one is rapid deceleration injury. Abrupt forces putting stress on carina and the cricoid cartilage play role in the mechanism. And lastly clothsline type injury, which we encounter in hang cases. The cervical trachea gets compressed in between the vertebrae.

\section{Accompanying Injuries}

Many associated injuries may be observed along with tracheal injuries. Most common ones are esophagus, recurrent laryngeal nerves, cervical spine, spinal cord, larynx, carotid arteries, jugular veins, pulmonary parenchyme, heart and great vessels of the thorax namely the aorta and the pulmonary vasculature.

In a series of 100 patients with primary injury of the cervical trachea, the most commonly encountered associated injuries were esophageal injury, hemopneumothorax, major vascular injury, recurrent nerve injury and spinal cord injury in decreasing rate of order (12). The same 
report designated that the most common associated injuries were hemopneumothorax, major vascular and intraabdominal injuries when the intrathoracic trachea was considered (12). Since the energy of the blunt trauma is quite high in intrathoracic tracheal injuries, the accompanying injuries are frequent. And these associated injuries may determine the prognosis.

\section{Diagnostic Workup}

As with any kind of trauma or emergency, the patent and effective airway is the first to be achieved. As many as $68 \%$ of blunt trauma cases have been reported to miss tracheobronchial injury diagnosis (13). With tracheal injuries, dyspnea and respiratory distress are present in almost all patients (14). Hoarseness is also frequent. Hemoptysis, palpable subcutaneous emphysema are the signs to be alert. In a penetrating neck trauma patient if the air leak from the wound disappears after intubation, this suggests that the lesion is proximal to the balloon of the endotracheal tube. In cases of penetrating neck injury, the escape of air from the lacerated skin is present in about $60 \%$ of patients with airway injury (15). The diagnosis first starts with suspicion. Following inspection and examination, X-ray imaging of the chest and neck is the quickest diagnostic modality. Falling lung sign of Kumpe may be observed as a result of the trauma separating the lung from the hilum. (16). Computerized tomography (CT) scan of the neck and thorax gives valuable information on mediastinal pathology. Nevertheless, CT is contraindicated when the trauma patient is hemodynamically unstable. Contrast esophagogram may be of use in penetrating injuries provided that the patient has stable status. Angiography may also be used for demonstrating the damage on the great vessels. Bronschocopy is golden standard in the diagnosis of the tracheal injury, hence some very small damage may not be visible. Both flexible and rigid bronchoscopy is of use, each one ha- ving its own advantages and disadvantages. Fiberoptic bronchoscopy is quick and easy to perform. It can help in proper intubation of the patient in transected trachea cases. It can also be used through the intubation tube. Appropriate manipulation of the endotracheal tube shall be performed in order not to miss any injured area covered by it. Rigid bronchoscopy is useful in cases where the trachea is completely transected. It helps through realignment of the transected distal part of the trachea and safe intubation (17). It also has its disadvantage such that general anesthesia is necessary. In cases of missed diagnosis, granulation tissue and eventual constriction of the airway occurs, which leads to respiratory symptoms. Chest X-ray, CT chest and three-dimensional CT along with bronchoscopy are helpful in determining the proper place of the stenosis in late diagnosis.

\section{Treatment}

The first step in the management of the tracheal injuries is securing the airway. The most common and convenient method is orotracheal intubation. In major tracheobronchial injuries the rate of orotracheal intubation was found to be $74 \%$. The percentages of fiberoptic bronchoscope intubation, intubation through the open neck wound and tracheostomy were 10, 10 and 5 respectively (14). Inappropriate intubation may cause rapid deterioration of the patient by detachment of the support tissues which may provide adequate airway and ventilation (18). Flexible bronchoscope might be of paramount importance since it has many advantages. The hyperextension of the neck is not necessary. It is performed easily in an awake patient with spontaneous ventilation. Sedation and paralysis, which are contraindicated in patients with unstable airway can be avoided. The distal part of the transected trachea can be visualized directly and the exact extent and location of the injury can be determined. Tracheostomy is usually not necessary but it must be performed af- 
ter 2 to 3 unsuccessful intubation attempts. In maxillofacial trauma cases, tracheostomy may be the immediate method. In some penetrating injuries the transected distal part of the trachea may retract inside the mediastinum. In such a case, manual examination and palpation of the distal part by inserting a finger inside the mediastinum and later on pulling out the trachea with the help of a clamp may be tried (19). Double lumen endotracheal tubes shall be avoided since they can aggravate the tracheal injury due to their bigger size. After the efficient airway has been established, one should evaluate the probable associated intrathoracic, neurologic, vascular, intraabdominal and vascular injuries. Once the effective and stable ventilation is warranted, such injuries like major cardiovascular maladies, subdural hematoma and intraabdominal bleeding shall be managed prior to the tracheal injury (5).

The anesthesiologist and the thoracic surgeon shall be in good communication in the management of the tracheal injuries. Jet ventilation is feasible for the surgeon since adequate amount of air can be delivered distal to the injury via a small bore tube. This makes the surgeon to get better sutures and easier mobilization of the trachea without resistance on the airway. Cardiopulmonary bypass is only needed when there are associated injuries relating to the heart and major vasculature. Almost all patients with simple tracheal injuries may be extubated at the end of the surgical repair process. But it postoperative endotracheal ventilation is necessary a larger size single lumen endotracheal tube shall be preferred, with which pulmonary toilet and fiberoptic bronchoscopy is easier. The cuff of the tube must avoid the site of the injury and must be placed accordingly (5).

Small injuries may be missed at the time of initial assessment of the patient. Most of the time they heal spontaneously without any need for surgery. Usually such minor injuries don't need any surgical intervention and heal satisfactorily if the size is confined to less than one third of the airway circumference (5).

Conservative treatment and close follow-up is usually ample when the ventilation is satisfactory without interruption of the tidal volume; minor laceration of the airway is present; minor subcutaneous emphysema is observed; tears of less than one third of the airway size takes place; when there is no documented sign of mediastinitis; and when simple tube thoracostomy is enough for the expansion of the collapsing lung and there is no persistent air leak $(20,21,22)$.

Different types of incisions facilitate the repair of the injury according to the involved section of the trachea. When the injury involves the proximal half or two thirds of the trachea the incision of choice shall be low cervical collar one. When the incision is elongated over the manubrium at the level of the second intercostal level, better exposure of the middle third of the trachea may be obtained. Injury of the lower part of the trachea, carina or right main stem bronchus favors a right posterolateral thoracotomy. When associated heart or major cardiopulmonary vasculature is present, median sternotomy may be performed depending of the location although it is not the ideal incision for the management of tracheal injuries. Anterior aspect of the airway at the carinal level may be visualized. This also needs the release of some main structures like the superior vena cava and aortic arch. Clamshell incision may be of use in associated injuries involving the heart and great vessels (5).

Primary small and clean lacerations are usually repaired by simple interrupted absorbable sutures. Sometimes, running sutures may be used. On the posterior membranous aspect of the trachea running sutures may be preferred, while anterior cartilaginous part favors simple interrupted tissues. Sutures shall avoid the tracheal 
lumen so that granulation tissue and stricture can be avoided. However the injury must not contain nonliving debris suggesting

impaired vascularization. When there are lots of nonviable tissues at the site of injury, debridement must be performed paying attention to keep as many vascularized healthy tissue as possible, which is the main key in proper healing process. The damaged nonviable tissue at both ends of the transected airway shall be trimmed and anastomosed end to end (23). One has to be meticulous at the trimming of the injured ends since excessive removal may lead to size mismatch and tension at the site of anastomosis. Most of the time it is possible to resect up to half of the trachea by releasing the surrounding tissues. For limited resections blunt development of the pretracheal fascia and flexion of the neck is enough. For more extended resection of the proximal trachea suprahyoid laryngeal release may be performed. Thus, primary resection and reconstruction may be the primary management method for trachea. When it comes to the carina, repair is a better option since resection and reconstruction may be somewhat troublesome. After tracheal repair a suture from the chin to the sternum may help guard the flexion of the neck, which is necessary for decreasing the tension at the site of anastomosis (24). Postoperatively pulmonary toilet and bedside bronchoscopy are important since the patients' ability to clear the airway secretion is limited. The patients who are on mechanical ventilation must be managed with the lowest airway pressure levels. Bronchoscopy should be performed at around 10 days to examine the anastomotic site. Anostomotic dehiscence and restenosis may be as high as $6 \%$ following tracheal reconstruction (25). Anostomic dehiscence may be life threatening as it may develop fistula to the brachiocephalic trunk. This is an emergent surgery indication. When tracheoesophageal fistule develops; division, primary repair and healthy adjacent tissue interposition in between is the way for management. In cases of missed diagnosis at the time of the impulse, failure to deal with the tracheal injury because of the more important life threatening associated injuries and postoperative complications; late management may be mandatory. As the unnoticed injury heals it develops granulation tissue leading to strictures in 1 to 4 weeks. The common management of such strictures is resection and primary reconstruction although some cases may be managed with bronchoscopy and dilatation (24). In some cases of blunt trauma a very rare case of tracheoesophageal fistula formation may be observed as a result of hematoma formation between trachea and esophagus at the time of the impact (26). In cases of late manifestation it is never late to make resection and primary reconstruction as long as distal suppuration is not documented.

\section{Conclusion}

Tracheal injuries although rare are an important group. With the improvement of prehospital medical care the incidence is expected to increase in time. All medical team including the paramedics, emergency service physicians, surgeons, anesthesiologists and intensive care doctors must be aware of the etiology, diagnosis and treatment. Mainstay of the tracheal injuries is suspicion, early diagnosis and prompt management.

\section{References}

1.Winslow WH. Rupture of bronchus from wild duck. Philadelphia Med Times 1871; 1: 225.

2.Treasure T. Dr Winslow's Duck: Correction of a Surgical Myth Concerning Tracheobronchial Injury. Ann Thorac Surg 2016;102:1762-7. 3.Ülkü R. Trakeobronşiyal Yaralanmalar. In: Yüksel M, Balcı AE. Göğüs Cerrahisi Kırmızı Kitap (2. Bask1) İstanbul, Nobel Tıp Kitabevleri, 2015: 791-7.

4.Gil T, Warmus J, Wlodarcyzk J, Grochowski 
Z, Bederski K, Kocon P, Talar P, Kuzdzal J. Iatrogenic injuries to the trachea and main bronchi. Kardiochir Torakochirurgia Pol. 2016;13(2):113-6

5.Wood DE, Karmy-Jones R. Tracheobronchial Trauma. In: Patterson GA, Cooper JD, Deslauriers J, Lerut AEMR, Luketich JD, Rice TW. Pearson's Thoracic and Esophageal Surgery (Third Edition), Philadelphia, Churchill Livingstone Elsevier, 2008, 1755-67.

6.Schneider T, Volz K, Dienemann H, Hoffmann H. Incidenceandtreatmentmodalitiesoftracheobronchial injuries in Germany. Interactive CardioVascular and Thoracic Surgery 2009;8:571-6

7.Lee RB. Traumatic injury of the cervicothoracic trachea and major bronchi. Chest Surg Clin N Am 1997; 7: 285-304

8.Bertelsen S, Howitz P. Injuries of the trachea and bronchi. Thorax 1972; 27: 188-94

9.Lynn RB, Iyengar K. Traumatic rupture of the bronchus. Chest 1972; 61:81-3

Kirsch MM, Orringer MB, Behrendt DM, Sloan

10.H. Management of tracheobronchial disruption secondary to non-penetrating trauma. Ann Thorac Surg 1976; 22:93-101

11.Estridge CE, Hughes FA, Jr, Pate JW, Cole F, Richardson R. Tracheobronchial injury caused by blunt trauma. Am Rev Respir Dis 1970; 101:230-7

12.Kelly JP, Webb WR, Moulder PV, Everson $\mathrm{C}$, Burch BH, Lindsay ES. Management of airway trauma: I. Tracheobronchial injuries. Ann Thorac Surg 1985; 40:551-5

13.Taskinen SO, Salo JA, Halttunen PE, Solvijarvi AR. Tracheobronchial rupture due to blunt trauma: A follow-up study. Ann Thorac Surg. 1989; 48:846-9

14.Rossbach MM, Johnson SB, Gomez MA, Sako EY, Miller OL, Calhoon JH. Management of major tracheobronchial injuries: A 28-year experience. Ann Thorac Surg 1998; 65:182-6

15.Symbas PN, Hatcher JCR, Vlasis SE. Bullet wounds of the trachea. $J$ Thorac Cardiovasc
Surg 1982; 83:235-8

16.Kumpe DA, Oh KS, Wyman SM. A characteristic pulmonary finding in unilateral complete bronchial transection. Am J Roentgenol Radium Ther Nucl Med. 1971;110 (4):704-6

17.Barmada H, Gibbons JR. Tracheobronchial injury in blunt and penetrating chest trauma. Chest 1994; 106:74-8

18.Baumgartner F, Sheppard B, de Virgilio C, Esriq B, Harrier D, Nelson RJ, Robertson JM. Tracheal and main bronchial disruptions after blunt chest trauma: presentation and management. Ann Thorac Surg. 1990;50(4):569-74 20.Mathisen DJ, Grillo H. Laryngotracheal trauma. Ann Thorac Surg 1987; 43:254-61

21.Kiser AC, O'Brien SM, Detterback FC. Blunt Tracheobronchial Injuries: Treatment and Outcomes. Ann Thorac Surg 2001;71:2059-65

22.Koletsiz E, Prokakis C, Baltayiannis N, Apostokalis E, Chatzimichalis A, Dougenis D. Surgical decision making in tracheobronchial injuries on the basis of clinical evidences and the injury's anatomical setting: A retrospective analysis. Injury. 2012;43:1437-41

23.Schneider T, Konstantina S, Dienemann H. Management of Iatrogenic Tracheobronchial Injuries: A retrospective analysis of 29 Cases. Ann Thorac Surg 2007; 83:1960-4

24.Mitchell JD, Mathisen DJ, Wright CD, Wain JC, Donahue DM, Moncure AC, Grillo HC. Clinical experience with carinal resection. J Thorac Cardiovasc Surg 1999; 117:39-52

25.Wood DE, Vallières E, Karmy-Jones R. Tracheobronchial resection and reconstruction. Semin Respir Crit Care Med 1999; 20:463

Grillo HC, Zannini P, Michelassi F. Complications of tracheal reconstruction. J Thorac Cardiovasc Surg 1986; 91:322-8

26.Stephens KE, Wood DE. Bronchoscopic management of central airway obstruction. J Thorac Cardiovasc Surg 2000; 119:289-96 